\title{
INTERNATIONAL COOPERATION OF AGRICULTURAL PUBLIC ORGANIZATIONS OF UKRAINIAN PROVINCES OF THE RUSSIAN EMPIRE (EARLY 20TH CENTURY)
}

The purpose of the article is to study the international cooperation of agricultural societies and its impact on the modernization of Ukrainian provinces. The author used comparative, chronological, problem and analytical research methods. On the basis of archival documents and the press of that time the author described and systematized new materials about the international activity of agricultural societies of the Ukrainian provinces. The author proves that it took various forms and contributed to the borrowing of useful foreign experience.

It was found that international activities had developed from personal ties to mutual cooperation. The public's tasks include holding numerous events. The author reconstructs the process of participation of members of agricultural organizations in various international events, including exhibitions. It was emphasized that these contacts were of mutual interest. They provided an opportunity for members of voluntary associations to learn from foreign experience. It is important that the experience was taken consciously.

Considerable attention is paid to the initiatives of individuals - members of agricultural societies. The trips contributed to positive changes in society and the modernization of the region in general. The article examines the issue of conducting tours, practices for local landowners abroad by agricultural associations. The expediency of such forms of cooperation was realized by members of agricultural societies. The public understood the need for change.

We drew attention to a wide range of countries with which representatives of agricultural societies cooperated. The public of the Ukrainian provinces was interested in foreign governmental and public institutions in the field of agriculture. There was a search for new forms of work, among which is the creation of the socalled American agency.

Foreign relations of Volyn hop growers should be called indicative. The joint work of representatives of the Volyn Hop Society was carried out together with government experts, foreign partners, including Ukrainian cooperatives in London. The initiative of agrarian public organizations received government assistance, and export chambers were established. Agricultural societies became their active participants and co-founders.

It is concluded that the adoption of foreign experience and contacts with foreign organizations and professionals have contributed to qualitative changes in society.

Key words: Russian Empire, Ukrainian provinces, public organization, agricultural societies, agriculture, international cooperation.

Ukraine had its own traditions of functioning voluntary associations. Their appearance testified to the emergence of elements of civil society, the gradual transition from traditional to modern community. It is important and urgent to study the historical experience of agricultural societies, including international cooperation.

Lysenko Maiia Stanislavivna - PhD (History), Associate Professor, O. M. Beketov National University of Urban Economy in Kharkiv (Ukraine). ORCID: 0000-0002-4135-4345. 
The period of the second half of the 19 - early 20 centuries became a transition for the history of the Russian Empire in general and the Ukrainian provinces in particular. There were changes in lifestyle, values, relationships between people. Public associations laid the foundation for cooperation between representatives of different strata, the center and the regions. The small cosmopolitan elite has given impetus to transformation both in individual regions and in the Empire as a whole. This movement created necessary conditions for reforming all spheres of society "bottom-up".

The object of the study are public organizations, which were called agricultural societies, and the subject of the study - the directions and forms of international cooperation of these voluntary associations.

The chronological boundaries of the article cover the period of the early 20th century, when international cooperation was actively developing. Territorial borders: nine Ukrainian provinces that were a part of the Russian Empire during the period under study.

The methodological basis of the article is the generally accepted principles of historicism, objectivity, systematics and complexity. As for research methods, we used methods of analysis and synthesis, critique of sources, thematic, problemchronological, etc.

The research topic has received some development in historical science. Literature on social and socio-economic issues can be divided into three stages: 1) prerevolutionary; 2) the Soviet period; 3) modern. During all stages of the publication we refer to: a) summaries on the history of the Russian Empire and Ukraine; b) from the history of economics, in which agricultural companies were mainly covered earlier; c) works on the history of public organizations, culture, education; d) personalities of figures; e) works specifically on the history of agricultural societies.

Pre-revolutionary historiography consisted of works by members of agricultural societies, written at different times which revealed important problems of socioeconomic and socio-political nature [1]. The activities of agricultural societies were to some extent covered in pre-revolutionary encyclopedic publications [2].

Despite the significant number of issued works published in the late 19th and early 20th centuries, their value mostly lies in the large amount of factual material presented. The authors of these publications were not only theorists, but mostly practitioners and activists of agricultural societies. This was the reason for the onesidedness of the historical material they represented. They did not set themselves the task of a comprehensive scientific analysis of this area of social activity.

Of particular importance in Soviet historiography of the problem were the works of A. D. Stepansky, published in the 1970's - early 1980's. The author considered agricultural societies as voluntary associations of Imperial Russia. For the first time in Soviet historical science, he classified and evaluated the activities of agricultural societies [3]. He wrote that «bourgeois-landlord» organizations were divided into representative (which included only the owners) and support types. A. D. Stepansky attributed agricultural societies to the former.

The vast majority of Soviet researchers assessed the role of agricultural societies in the 19th and early 20 th centuries positively, although they were forced to admit in connection with the existing ideological orientation that in the conditions of tsarism and the dominance of large landownership, these societies could not significantly influence the socio-economic and political situation in the country. [4]. Scientists mainly studied 
the activities of industry associations of all-Russian scale (Free Economic Society and Moscow Agricultural Society) [5]. At the same time, some regional societies, especially those operating in the Ukrainian provinces, were not considered at all. Their public activities were not studied. In general, the historiography of the Soviet period on the study of voluntary associations of the 19 - early 20 centuries. is quite impoverished and one-sided.

After 1991, the latest stage of the study of the society of the Russian Empire began. Its main features are the absence of ideological taboos, publicization of issues not only of political and socio-economic development in the national dimension, but also thorough elaboration of events, processes, phenomena at regional and local levels, humanization of history, overcoming stereotypes that emerged in the Soviet era. Historians began to study not only public policy but also society, its formation and influence on the development of both the empire as a whole and individual regions.

O. P. Reyent and O. V. Serdyuk analyzed the situation in agriculture and the food market of Ukraine and the world [6]. The approach to the study of the country's development through the prism of modernization is implemented in general works on the history of the Russian Empire [7], monographs, which explore and analyze the process of modernization [8].

The most significant phenomenon in this context was the appearance of a number of works by B. M. Mironov. He focused the interaction of the state on society in the Russian Empire, beginning in the late 18th century and up to the revolution of 1917, and gave an original judgment about the mental, sociopsychological types of certain groups of the population, the peculiarities of the origin and functioning of public organizations [9].

The works of Ukrainian historians V. V. Kravchenko, D. M. Chorny demonstrate thorough achievements in covering economic, urban and nation-building processes in the Ukrainian provinces of the empire in the second half of the 19thearly 20th century [10].

Thus, modern Ukrainian historians take the studies of their predecessors quite seriously. Their work features a new methodology aimed at getting rid of outdated stereotypes. This concerns, first of all, the shift of attention from the central imperial societies to the provincial ones, the search for local differences in the activities of branch associations. The concepts put forward by Ukrainian researchers expand the idea of the place of agricultural societies in the development of agricultural science, education and social life of the second half of the 19 - early 20 centuries. The main attention of historians is focused on the characteristics of government policy, qualitative changes in the agricultural sector, the demonstration of educational and research activities of individual agricultural societies in Ukraine.

Modern Russian researchers also study the activities of agricultural societies of the Russian Empire in the 19th - early 20th century. For example, the publications of the 1990s and 2000s concerned either a single agricultural society or branch societies of the empire or its particular region. Published scientific research by O. O. Kuryonishev, S. A. Kozlov on Moscow Agricultural Society, V. V. Sviridov - on agrarian associations of the Tambov province [11].

In the second half of the 1990 s - beginning of the 21 century due to the growing interest of researchers in the formation of the foundations of civil society and the rule of law in the Russian Empire, scientific studies have appeared that examine the history of 
pre-revolutionary public organizations. It is especially worth noting here a number of meaningful works byA. S. Tumanova, devoted to the activities of public organizations of imperial Russia, government policy towards them [12]. Articles and a monograph by Russian researcher $\mathrm{O}$. Yelina attract attention with original approaches to covering the problem [13].

Scientists of the diaspora and abroad study the general processes of the history of the Russian Empire, for example, the American historian R. Pipes gave a new vision of the problem of formation of Russian statehood, its main principles, as well as the specifics of socio-political processes of the Russian Empire in comparison with Western Europe [14]. The works of the French historian D. Beauvoir reveal the causes and essence of the Ukrainian-Polish-Russian conflict during the late empire [15].

As part of the study of the history of Russia, public organizations of the country are studied. In particular, J. Bradley considered agricultural societies more scientific societies than production and marketing. The works of Theodore Shanin, devoted to the peasantry or the "uncomfortable class", are relevant to the subject of the study [16].

Thus, the historiographical analysis of the literature on the research topic showed that the published works do not comprehensively reveal the main aspects of the activities of voluntary agrarian associations of the Ukrainian provinces of the Russian Empire. Researchers did not pay attention to such issues as the influence of public organizations on the modernization of the agricultural sector, their international cooperation, the participation of landowners, scientists and entrepreneurs in the public life of the Ukrainian provinces.

The study uses different types of sources, shows the features of their use. These include: 1) archive documents; 2) legislative acts; 3) reference documentation; 4) statistical and reference publications; 5) periodicals; 6) sources of personal origin; 7) visual sources.

The basis of the study are the documents of the archives. The author has processed the archival funds of several institutions. We were guided by the idea of the need to study the regional and central archives of the country, which once housed the councils of provincial agricultural societies. Thus, the author covered the following archives of Ukraine. Headquarters in Kyiv: Central National Historical Archive of Ukraine. Among the regional archives, we conducted work in Kharkiv, Odesa, Zaporizhia and Zhytomyr.

The activity of agricultural societies is thoroughly covered in reference prerevolutionary publications, which expressed the official government position on the activities of these organizations and performed primarily a cognitive function, in contrast to special scientific publications [17].

In addition to general reference books, industry reference books also appeared in the Russian Empire, among which we single out S. M. Bogdanov's. It contains an analysis of the activities of agricultural institutions established before 1893, including societies [18].

A significant place in the source analysis of our study is occupied by central and local periodicals that cover various aspects of the formation and operation of agricultural societies, their social, professional and personal composition, relationships with government, the public and other societies.

In general, the characteristics of the source base give reason to conclude that it is sufficient to study the above topic. 
The purpose of the article is to study the formation of international cooperation of agricultural societies of Ukrainian provinces and its impact on the modernization of Ukrainian provinces.

The American historian R. Pipes insisted that in the Russian Empire «there were no incentives to improve agriculture. Only external conditions, such as trade relations with other countries or significant scientific and technological innovations could help» [14].

We believe that one important clarification should be accepted with this statement: the public, gathered around agricultural societies, understood the need for cooperation. However, for a long time it was hampered by insufficient financial capacity, in particular the poverty of the majority of the population. For a long time, foreign trips could be made mainly by nobles. They were the most educated, well-off. Under the influence of foreign experience, landowners gradually changed their judgments and views. Studying the achievements of Europe, the nobles thought about similar processes abroad and at home. Eventually, these relationships between individuals and organizations became not sporadic but permanent. The circle of people who for various reasons (business affairs, rest or treatment, training) were abroad has expanded. At the turn of the 19-20 centuries the public began to pay special attention to economically developed countries, especially Europe and the United States. International activities gradually became relevant for public organizations.

Relations with foreign members of public associations, institutions and organizations have become an important aspect of the work of agricultural societies. This cooperation manifested itself in various forms. For example, agricultural societies sent their members for internships, participated in international exhibitions, later established business contacts, opened branches. Moreover, foreign experience has shown the significant impact of such public associations on society and the economy. There were changes in the consciousness and worldview of the public, which became a characteristic feature of modernization of society.

Isolated examples of the stay of agricultural workers abroad were observed in the second half of the 19th century, in particular by the landowner of Poltava province L. V. Kochubey. However, it acquired a systemic character in the early 20 th century. At the same time, the direct participation of agricultural societies in exhibitions abroad were becoming widespread. In particular, the Odessa Agricultural Society successfully exhibited its goods at the World Exhibitions in Paris (1867) and Vienna (1873) [19, оп. 1. спр. 253. арк. 37; спр. 271. арк. 406]. At the Paris Exhibition in 1900, the Kharkiv Agricultural Society presented a collection of agricultural products produced in the Kharkiv province in significant quantities that were of interest to Europe as an export item. Data on the Kharkiv province were placed in the pavilion of the Kharkiv Agricultural Society: agricultural map, meteorological cartogram, etc. It provided assistance and support to individual owners, taking care of the delivery and placement of exhibits at the exhibition. To participate in the exhibition, the company received a zemstvo subsidy of 2,500 rubles [20, ф. 304. оп. 1. спр. 390. арк. 1-2].

International activities were part of the task and were carried out by all agricultural societies, especially provincial ones.

The Podolsk Agricultural Society also maintained ties with foreign entrepreneurs, including British ones. For example, at a meeting of the Society's Council on January 27, 1912, the chairman, Count O. M. Tyszkiewicz, announced that a group of British 
capitalists had sought to establish a network of elevators in order to improve the quality of grain exports from Russia to Great Britain. The meeting called for the construction of granaries and elevators to be «a very desirable and urgent need» $[21$, Протокол заседания совета Подольского общества сельского хозяйства от 27 января1912 года. 1912. № 1. С. 5-9].

The Kyiv Agricultural Society maintained ties with the German Bacteriological Institute and the US Department of Agriculture. First of all, they were interested in the control of harmful agricultural insects and animals [22, оп. 1. спр. 8. арк. 15]. The Agrarian Association, through the Kyiv Society of Western Zemstvos and the Kharkiv Agricultural Society (its branch of the American Agency), purchased agricultural machinery and seeds for the western provinces [23, оп. 1. спр. 138. арк. 320]. Agricultural societies of Ukrainian provinces conducted two excursions of landowners to Great Britain [24, Вторая экспедиция русских хозяев в Англию. 1902. 28 февраля. С. 2-4].

Until 1908, there was a NorthAmerican agency under the Ekaterinoslav Provincial Zemstvo. It was a representative office in the United States that performed various functions. In particular, relations were maintained with institutions that could deliver seeds, tools, and fertilizers. Cultural work was also carried out - acquaintance of Russian farmers and agronomists with the establishment of agriculture in America, in particular with governmental and public institutions for the rise of the agricultural sector in the United States [20, ф. 237. оп. 1. спр. 9. арк. 5].

The activities of the American agency were not only educational, it concerned trade and marketing. For specialists of the Ukrainian provinces it was necessary to study the methods of cultivation of land, plants important for cultivation in the Ekaterinoslav region. Measures to establish agronomic aid in the United States were studied, especially the methods and techniques of establishing links between American research institutions and the general population. Ways to obtain meat products and information about breeds of cattle were studied. It was necessary to monitor the success of agricultural engineering. Representatives of agricultural societies were interested in many other issues, in particular, they tried to describe the American methods of arrangement and repair of roads, water management, irrigation and drought control [25, оп. 1. спр. 9. арк. 7]. In general, this corresponded to the modernization process taking place at that time in the Ukrainian provinces.

For various reasons, the American agency of the Ekaterinoslav Provincial Zemstvo in 1908 was transferred to the Kharkiv Agricultural Society. An agent of the American agency began to be appointed in America on behalf of the Kharkiv Agricultural Society. In 1910 he was I. B. Rosen - a specialist with higher agronomic education and fluency in English. He was paid a salary of 10,000 rubles [26, оп. 1. спр. 275. арк. 146147]. The agent reported on his progress every October.

The Kharkiv Agricultural Society, through its American agency, organized a trip of landowners from Ukrainian provinces to the United States. The author could not find the report on the trip itself, but the plan of the event itself deserves attention. The draft of the trip indicated that first of all it was necessary to visit areas similar in climate to the local ones. When getting acquainted with the economy of these states, it was worth paying attention to the impossibility of full borrowing and transfer of the norms developed by them to local conditions. It was proposed 
to pay special attention to the work of research stations [24, Вторая экспедиция русских хозяев в Англию. 1902. 28 февраля. С. 2]. It was rightly believed that future improvements in the field would be associated with advances in science and cooperation with scientific institutions.

At the same time, landowners were advised to look at several farms in the states of New England with a highly intensive economy. «There Russian owners would have the opportunity to get acquainted with the organization of intensive dairy farming, poultry, horticulture and other industries. In addition to individual sectors of the economy, it would be desirable to find out the features of the organization of both small farms and large farms in different areas. In addition, not only highly specialized, but also more versatile, suitable for Russian conditions» [24, Экскурсия в Америку. 1910. 14 февраля. С. 17].

Of particular interest is the tour-acquaintance with the organization in America of special unions (livestock and others), as well as general unions, enterprises and institutions for the sale of bread and livestock products - cooperatives, elevators, shops, credit and agronomic assistance to the population were also be included in the tour program. It was desirable to visit exhibitions and congresses. Thus, in the list of tasks we find the study of community service in America [24, Экскурсия в Америку. 1910. 14 февраля. С. 18].

Therefore, the tour should (according to the members of the Council of the Kharkiv Agricultural Society) focus on getting acquainted with the economy of the states, close in natural conditions with the southern provinces of the Russian Empire. With the organization of assistance to this economy by the government, society and cooperatives. Representatives of the Kharkiv Agricultural Society hoped that local farmers would benefit from learning from the positive experience.

«The route of the future tour was imagined as follows. The road from Hamburg to New York. Across America from New York to New England to Chicago, from Chicago through Wisconsin to Minneanopolis, from there through Dakota, Nebraska, Kansas to St. Louis and New York» [24, Экскурсия в Америку. 1910. 14 февраля. С. 19]. The event provided an idea of the scope of the Kharkiv Agricultural Society and its practical orientation. Thus, the provincial society could maintain international relations.

Landowners of Ukrainian provinces adopted the experience of other nations. For example, the owner of the Ekaterinoslav province, Ivan Shintur, studied agronomic science and practice in the modern Czech territory and Moravia, as mentioned in the two-week journal of the Ekaterinoslav Agricultural Society [27, Отчет Ивана Шинтуря о поездке в Чехию и Моравию для изучения сельского хозяйства в 1914 году. 1914. № 1. С. 11-16].

Foreign specialists also worked in the Ukrainian provinces. Incidentally, a lot was written about the experience of the Czechs not only in the press but also in journalism. In the newspapers you can find feuilletons about specialists from AustriaHungary. They were reproached with their bad work, accussed of being low-skilled experts who came to the Ukrainian provinces for high salaries; they often changed jobs, deceived the public and zemstvos [24, Фельетон.Чехи в русской агрономии. 1913. 19 сентября. С. 6-11]. However, highly qualified and honest workers, in particular F. I. Heyduk, were dedicated to the work of foreign specialists. He worked 
in the PoltavaAgricultural Society and contributed to the development of relations with landowners of Poltava and Kharkiv provinces. This is what our article is about ${ }^{1}$.

At the same time, the practices of individual trips abroadand joint business trips of members of agricultural societies weer developed. In the early 20 th century theybecame more numerous. The state largely funded foreign events, especially exhibitions and research activities.

Members of agricultural societies were sent on business trips abroad on various issues. In particular, in 1911 B. K. Enken from the Kharkiv breeding station (which was structurally part of the Kharkiv Agricultural Society) went to get acquainted with the case in Germany. Kharkiv Agricultural Society has allocated 1,000 rubles for the trip [25, оп. 1. спр. 8. арк. 47]. В. K. Enken visited a brewery exhibition in Berlin. In one of the correspondences for «Южнорусской сельскохозяйстенной газеты» he emphasized, «there is a big difference between our Russian and German exhibitions. There is nothing superfluous here. There are not even the usual exhibition decorative props, because the exhibition is not intended for the general public and not for entertainment, but for business. Everything is arranged to the extreme simplicity from the outside, but very thoughtful and convenient in terms of content» [24, Енкен Б. Письма из-за границы. IV Берлинская пивоваренная выставка. 1911. 22 ноября. С. 11-12]. This situation is explained by the different level of business development in both countries and the needs of the public. Using such opportunities, agricultural societies taught domestic experts to modernize the whole range of issues related to agricultural production in rural areas.

Some representatives of agricultural societies went abroad on their own to learn the necessary experience, but not all had such an opportunity. In particular, a member of the Kharkiv Agricultural Society I. K. Grishchenko, owner of the multidisciplinary farm «Українка» and a brewery, traveled to Germany every year. There he observed the technological process of beer production, adopted the latest technological innovations. In general, I. K. Grishchenko tried to make their enterprises meet modern standards in production at that time. However, this example cannot be called typical.

On the other hand, representatives of voluntary associations of Ukrainian provinces cooperated with similar organizations in other regions of the Russian Empire, in particular «Русское зерно». Together, they had better internship opportunities in exemplary farms. This information is covered by us in another article 2 .

Hop growers actively supported international relations. In the south-western Ukrainian provinces this was done with the help of the Volyn Hop Society. Among the countries that bought Volyn hops, we should mention France, Great Britain, the Scandinavian countries, Japan, and the United States. Before «conquering» the market of each country, the company advised to use an individual approach. For example, in the United States, Volyn hops were sold through the American agency of the Kharkiv Agricultural Society ${ }^{3}$. In the UK, hops were sold through Ukrainian cooperatives in

\footnotetext{
${ }^{1}$ Лисенко М. С. Аграрна модернізація Харківської губернії: погляд іноземця (1860-ті рр.). Вісник Харківського національного університету імені В. Н. Каразіна. Серія: «Історія України. Українознавство: історичні та філософські науки». 2017. Вип. 25. С. 41-45.

${ }^{2}$ Lysenko M. S. «Russian Grain» and the Agrarian Organizations in the Early XX Century. Вісник Харківського національного університету імені В. Н. Каразіна. Серія: «Історія України. Українознавство: історичні та філософські науки». 2018. Вип. 27. С. 36-41.

${ }^{3}$ The Kharkiv Agricultural Society had its representative office (agency) in the United States, which performed various functions.
} 
London ${ }^{4}$. The hops were traded with France through the Russian-French Chamber of Commerce. Commercial relations with foreign countries were undoubtedly one of the most important factors in the success of commercial, industrial and financial enterprises of the Russian Empire. Significant progressive development of foreign trade in the early 20 th century showed that merchants understood the importance of international trade for them and how they could benefit from it. France was one of the most interesting markets. Political motives had some influence on the development of trade relations between the two countries. In addition, the French merchants, who were distinguished by their creditworthiness and meticulousness in business, were desirable buyers. Branches of the Russian-French Chamber of Commerce were established in Moscow and Warsaw. They were in constant contact with the central government. Their task was to study all issues of commercial and industrial nature. Volyn hop growers carried out trade operations through the Warsaw branch of the Chamber of Commerce. Employees of the Volyn Hop Growing Society and personally instructor I. I. Zasukhin corresponded and kept in touch with international companies [28, оп. 1. спр. 27. арк. 5].

With the outbreak of World War I, hop growers faced serious problems. The State Duma passed a law banning the consumption of vodka, including beer. The war led to a general economic decline due to hostilities on the territory of Ukraine, the sequestration of hop plots by German colonists. In 1918-1919, the situation stabilized in the sense that the ban on the production of vodka was lifted. However, the general economic situation, low purchasing power of the population did not bring the industry to pre-war levels. International cooperation lasted until 1919.

Extensive and direct relations with foreign markets were fully understood by the public of the Ukrainian provinces of the Russian Empire. The task of creating a central body for exports was raised by different meetings and congresses, in particular the Odessa Trade and Industry Congress. During the three years (1907-1910), the following chambers of commerce were established on the initiative of interested persons to facilitate trade: Russian-English, Russian-Belgian, Russian-Slavic [20, оп. 1. спр. 2732. арк. 11].

The Russian Export Chamber was established in 1910 to centralize the business and assist public organizations in relations with foreign institutions and partners. Its tasks included: to study foreign markets, as well as export business, to assist individuals and institutions in the development of Russian exports on the right basis, to report conclusions on exports to government, public institutions and individuals; collect, develop and disseminate statistical and other information related to trade in Russia and other countries. Organize readings, reports, publish books, brochures, bulletins, periodicals and all kinds of printed materials on Russian exports; to organize congresses, museums on the history of trade, exhibitions in Russia and abroad with proper permission, to organize Russian departments at international exhibitions, etc. The Export Chamber was divided into departments: grain trade, perishable products (meat, butter, eggs, fish, poultry); forest; factory. Later, an information bureau was established. Zemstvos made a membership fee to the Russian Export Chamber in the amount of 200 rubles. New departments of the Export Chamber were opened in 1912 - flour and handicraft. Provincial agricultural societies were considered full members of the Russian Export

${ }^{4}$ This refers to cooperatives founded by Ukrainians from Galicia in London. 
Chamber. Some of them, for example, the Kharkiv Agricultural Society were members of the Russian-American Chamber of Commerce (1916) [25, оп. 1. спр. 23. арк. 50].

Thus, agricultural societies were actively engaged in international activities. Gradually, they moved from individual contacts to mass ones. International cooperation consisted of several areas. Participation in international exhibitions, excursions to intensive farms of other countries became useful. A new form of work was the establishment of branches and representative offices abroad, in particular, the American agency of the Kharkiv Agricultural Society. International relations were maintained through partners and the public abroad. Some tasks were solved by the state at the allRussian level by establishing the necessary institutions, including export chambers. Agrarian associations also became members of export chambers.

Prospects for further exploration in this direction may be a study of agricultural societies of Ukrainian provinces with Ukrainian cooperatives in London.

1. Исторический обзор 50-летней деятельности Императорского общества сельского хозяйства Юга России / сост. М. П. Боровский. Одесса : Тип. П. Францева, 1878. 274 с.; Тихомиров В. А. Историческая записка о деятельности Полтавского общества сельского хозяйства (1865-1887 гг.). Полтава : Тип. Н. Пигуренко, 1887. 183 с.; Рева И. М. Киевское общество сельского хозяйства и сельскохозяйственной промышленности и его деятельность. Киев : Тип. Ун-та Св. Владимира, 1892. 31 с.

2. Большая энциклопедия. Словарь общедоступных сведений по всем отраслям знания / под ред. С. Н. Южакова. Санкт-Петербург, 1903. Т. 17. С. 240-241; Т. 18. С. 470-471; Полная энциклопедия русского сельского хозяйства и соприкасающихся с ним наук. В XII т. СанктПетербург, 1912. Т. IX. С. 1138-1139.

3. Степанский А. Д. Йстория общественных организаций дореволюционной России. Москва : Наука, 1977. 96 с.; Його ж. Самодержавие и общественные организации России на рубеже XIX-XX вв. : учебное пособие по спецкурсу. Москва : Наука, 1980. 90 с.; Його ж. История научных учреждений и организаций дореволюционной России: пособие по спецкурсу. Москва : МГИАИ, 1987. 86 с.; Його ж. История общественных организаций в России на рубеже ХІХ-ХХ вв. : пособие по спецкурсу. Москва : МГИАИ, 1982. 92 с.

4. Ковальченко И. Д., Литваков Б. М., Селунская Н. Б. Социально-экономический строй помещичьего хозяйства Европейской России в эпоху капитализма. Москва : Наука, 1982.468 c.

5. Довженко И. Т. Сельскохозяйственные общества дореволюционной России, их особенности и размещение. Историческая география России ХП - нач. ХХ в. Москва, 1975. C. 207-216.

6. Реєнт О. П., Сердюк О. В. Сільське господарство України і світовий продовольчий ринок (1861-1914 рр). Київ : Інститут історії України, 2011.365 с.

7. Россия в начале XX века / А. Н. Сахаров, А. Н. Боханов, Л. С. Гатагова и др. Москва : Новый хронограф, 2002. 744 с.; Россия в I Мировой войне 1914-1918. Энциклопедия в 3 т. / отв. ред. А. К. Сорокин. Москва, 2014.

8. Травин Д., Маргания О. Европейская модернизация. В 2 кн. Москва : ООО «Изд-во АCТ»; Санкт-Петербург: Terra Fantastica, 2004. Кн. 1.

9. Миронов Б. Н. Социальная история России периода империи. В 2 т. Москва, 1999; Б. Н. Миронов Добровольные ассоциации и гражданское общество в позднеимперской России Журнал сочиологии и сочииальной антропологии. 2008. Т. 3. С. 164-176.

10. Кравченко В. В. Україна, імперія, Росія. Вибрані статті з модерної історії та історіографії. Київ : Вид-во Часопис «Критика», 2011. 544 с. ; Чорний Д. М. По лівий бік Дніпра: проблеми модернізації міст України (кінець XIX - початок XX ст.) : монографія. Харків : ХНУ ім. В. Н. Каразіна, 2007. 301 с.

11. Куренышев А. А. Сельскохозяйственная столица России : Очерки истории Московского общества сельского хозяйства (1820-1929 гг.) : монография. Москва : Изд-во АИРО, 2012. 203 с.; Козлов С. А. 175 лет Московскому обществу сельского хозяйства: традиции 
и новации. Науч. тр. Междунар. союза экономистов и ВЭО России. Санкт-Петербург, 1996. Т. 3. С. 232-240; Свиридов В. В. Сельскохозяйственные общества Тамбовской губернии (втор. пол. XIX - нач. XX вв.) : дис. ... канд. ист. наук. Тамбов, 2006. 219 с.

12. Туманова А. С. Самодержавие и общественные организации в России 1905-1917 гг. Тамбов : Изд-во Тамбовского гос. ун-та, 2002. 487 с.; Ії ж Общественные организации и союзы России в начале XX в. Россия и современный мир. 2002. №3 (36). С. 49-73.

13. Елина О. Ю. Местные сельскохозяйственные общества: на пути к аграрной модернизации России Историко-биологические исследования. 2012. Т. 4. № 3. С. 34-63; ІІї ж Опытные сельскохозяйственные станции Российской империи: тенденции развития на рубеже XIX-XX вв. Вестник Днепропетровского университета. 1998. Вып. 4. С. 96-110.

14. Пайпс Р. Россия при старом режиме. Москва : Независимая газета, 1993. 420 с.

15. Бовуа Д. Шляхтич, кріпак і ревізор. Польська шляхта між царизмом і українськими масами (1831-1863 рр.). Київ : РАУ, 1996. 420 с.; Бовуа Д. Битва за землю в Україні (18631914 рр.). Поляки в соціо-етнічних конфліктах. Київ : Критика, 1998. 196 с.

16. Брэдли Дж. Общественные организации в царской России: наука, патриотизм и гражданское общество. Москва : Новый Хронограф, 2012. 448 с.; Брэдли Дж. Гражданское общество и формы добровольных ассоциаций: Опыт России в европейском контексте. Гражданская идентичность и сфера гражданской деятельности в Российской империи. Bтор. пол. $X I X$ - нач. $X X$ вв. / отв. ред. Б. Пиетров. Москва : Российская полит. энциклопедия, 2007. C. 63-99; Shanin T. Russia as a «Developing society»/ ed. Macmillan. Houndmiles : Basingstoke, 1985. 162 p.

17. Адрес-календарь сельскохозяйственных обществ. Санкт-Петербург : Изд-во Министерства Земледелия, 1902.240 с.

18. Богданов С. М Иллюстрированный сельскохозяйственный словарь. Энциклопедия сельского хозяйства. Киев, 1895. 1446 с.

19. Держархів Одеської області. Ф. 22. Імператорське товариство сільського господарства Півдня Росії.

20. Держархів Харківської області. Ф. 304. Харківська губернська земська управа.

21. Справочный листок.

22. ЦДІАК України. Ф. 731. Київське товариство сільського господарства i сільськогосподарської промисловості.

23. ЦДІАК України. Ф. 573. Київське товариство західних земств 3 продажу сільськогосподарських машин, м. Київ.

24. Южнорусская сельскохозяйственная газета.

25. Держархів Харківської області. Ф.237. Харківське товариство сільського господарства і сільськогосподарської промисловості.

26. Держархів Запорізької області. Ф. 56. Олександрівська повітова земська управа.

27. Южное хозяйство.

28. Держархів Житомирської області. Ф. 187. Волинське товариство хмелярства.

\section{References}

1. Ystorycheskyj obzor 50-letnej dejateljnosty Ymperatorskogho obshhestva seljskogho khozjajstva Jugha Rossyy / sost. M. P. Borovskyj. Odessa : Typ. P. Franceva, 1878. 274 s.; Tykhomyrov V. A. Ystorycheskaja zapyska o dejateljnosty Poltavskogho obshhestva seljskogho khozjajstva (1865-1887 ghgh.). Poltava : Typ. N. Pyghurenko, 1887. 183 s.; Reva Y. M. Kyevskoe obshhestvo seljskogho khozjajstva y seljskokhozjajstvennoj prombshlennosty y egho dejateljnostj. Kyev : Typ. Un-ta Sv. Vladymyra, 1892. 31 s.

2. Boljshaja эncyklopedyja. Slovarj obshhedostupnыkh svedenyj po vsem otrasljam znanyja / pod red. S. N. Juzhakova. Sankt-Peterburgh, 1903. T. 17. S. 240-241; T. 18. S. 470-471; Polnaja эncyklopedyja russkogho seljskogho khozjajstva y soprykasajushhykhsja s nym nauk. V XII t. Sankt-Peterburgh, 1912. T. IX. S. 1138-1139.

3. Stepanskyj A. D. Ystoryja obshhestvennukh orghanyzacyj dorevoljucyonnoj Rossyy. Moskva : Nauka, 1977. 96 s.; Jogho zh. Samoderzhavye y obshhestvennыe orghanyzacyy Rossyy na rubezhe KhIKh - KhKh vv. : uchebnoe posobye po speckursu. Moskva : Nauka, 1980. 90 s.; Jogho zh. Ystoryja nauchnыkh uchrezhdenyj y orghanyzacyj dorevoljucyonnoj Rossyy: posobye po speckursu. Moskva : MGhYAY, 1987. 86 s.; Jogho zh. Ystoryja obshhestvennыkh orghanyzacyj v Rossyy na rubezhe KhIKh - KhKh vv. : posobye po speckursu. Moskva : MGhYAY, 1982. $92 \mathrm{~s}$.

4. Kovaljchenko Y. D., Lytvakov B. M., Selunskaja N. B. Socyaljno-эkonomycheskyj stroj pomeshhychj'egho khozjajstva Evropejskoj Rossyy v эpokhu kapytalyzma. Moskva : Nauka, $1982.468 \mathrm{~s}$ 
5. Dovzhenko Y. T. Seljskokhozjajstvennыe obshhestva dorevoljucyonnoj Rossyy, ykh osobennosty y razmeshhenye. Ystorycheskaja gheoghrafyja Rossyy XIX - nach. XX v. Moskva, 1975. S. 207-216.

6. Rejent O. P., Serdjuk O. V. Siljsjke ghospodarstvo Ukrajiny i svitovyj prodovoljchyj rynok (1861-1914 rr). Kyjiv: Instytut istoriji Ukrajiny, 2011. $365 \mathrm{~s}$.

7. Rossyja v nachale XX veka / A. N. Sakharov, A. N. Bokhanov, L. S. Ghataghova y dr. Moskva : Novыj khronoghraf, 2002. 744 s.; Rossyja v I Myrovoj vojne 1914-1918. Эncyklopedyja v 3 t. / otv. red. A. K. Sorokyn. Moskva, 2014.

8. Travyn D., Marghanyja O. Evropejskaja modernyzacyja. V 2 kn. Moskva : OOO «Yzd-vo AST»; Sankt-Peterburgh: Terra Fantastica, 2004. Kn. 1.

9. Myronov B. N. Socyaljnaja ystoryja Rossyy peryoda ymperyy. V 2 t. Moskva, 1999; B. N. Myronov Dobrovoljnыe assocyacyy y ghrazhdanskoe obshhestvo v pozdneymperskoj Rossyy Zhurnal socyologhyy y socyaljnoj antropologhyy. 2008. T. 3. S. 164-176.

10. Kravchenko V. V. Ukrajina, imperija, Rosija. Vybrani statti z modernoji istoriji ta istorioghrafiji. Kyjiv : Vyd-vo Chasopys «Krytyka», 2011. 544 s. ; Chornyj D. M. Po livyj bik Dnipra: problemy modernizaciji mist Ukrajiny (kinecj XIX - pochatok XX st.) : monoghrafija. Kharkiv: KhNU im. V. N. Karazina, 2007. $301 \mathrm{s.}$

11. Kurenushev A. A. Seljskokhozjajstvennaja stolyca Rossyy : Ocherky ystoryy Moskovskogho obshhestva seljskogho khozjajstva (1820-1929 ghgh.) : monoghrafyja. Moskva :Yzd-vo AYRO, 2012. 203 s.; Kozlov S. A. 175 let Moskovskomu obshhestvu seljskogho khozjajstva: tradycyy y novacyy. Nauch. tr. Mezhdunar. sojuza эkonomystov y VЭO Rossyy. SanktPeterburgh, 1996. T. 3. S. 232-240; Svyrydov V. V. Seljskokhozjajstvennыe obshhestva Tambovskoj ghubernyy (vtor. pol. XIX - nach. XX vv.) : dys. ... kand. yst. nauk. Tambov, 2006. 219 s.

12. Tumanova A. S. Samoderzhavye y obshhestvennыe orghanyzacyy v Rossyy 1905-1917 ghgh. Tambov : Yzd-vo Tambovskogho ghos. un-ta, 2002. 487 s.; Jiji zh Obshhestvennue orghanyzacyy у sojuzы Rossyy v nachale XX v. Rossyja y sovremennыj myr. 2002. \#3 (36). S. 49-73.

13. Elyna O. Ju. Mestnыe seljskokhozjajstvennыe obshhestva: na puty k aghrarnoj modernyzacyy Rossyy Ystoryko-byologhycheskye yssledovanyja. 2012. T. 4. № 3. S. 34-63; Jiji zh Oрыtпыe seljskokhozjajstvennыe stancyy Rossyjskoj ymperyy: tendencyy razvytyja na rubezhe XIX-XX vv. Vestnyk Dnepropetrovskogho unyversyteta. 1998. Vыр. 4. S. 96-110.

14. Pajps R. Rossyja pry starom rezhyme. Moskva : Nezavysymaja ghazeta, 1993. $420 \mathrm{~s}$.

15. Bovua D. Shljakhtych, kripak i revizor. Poljsjka shljakhta mizh caryzmom i ukrajinsjkymy masamy (1831-1863 rr.). Kyjiv: RAU, 1996. 420 s.; Bovua D. Bytva za zemlju v Ukrajini (1863-1914 rr.). Poljaky v socio-etnichnykh konfliktakh. Kyjiv : Krytyka, 1998. 196 s.

16. Brэdly Dzh. Obshhestvennыe orghanyzacyy v carskoj Rossyy: nauka, patryotyzm y ghrazhdanskoe obshhestvo. Moskva : Novыj Khronoghraf, 2012. 448 s.; Brэdly Dzh. Ghrazhdanskoe obshhestvo y formы dobrovoljnыkh assocyacyj: Opыt Rossyy v evropejskom kontekste. Ghrazhdanskaja ydentychnostj y sfera ghrazhdanskoj dejateljnosty v Rossyjskoj ymperyy. Vtor. pol. XIX - nach. KhKh vv. / otv. red. B. Pyetrov. Moskva : Rossyjskaja polyt. эncyklopedyja, 2007. S. 63-99; Shanin T. Russia as a «Developing society»/ ed. Macmillan. Houndmiles : Basingstoke, 1985. 162 p.

17. Adres-kalendarj seljskokhozjajstvennыkh obshhestv. Sankt-Peterburgh : Yzd-vo Mynysterstva Zemledelyja, 1902. $240 \mathrm{~s}$.

18. Boghdanov S. M Ylljustryrovannыj seljskokhozjajstvennыj slovarj. Эncyklopedyja seljskogho khozjajstva. Kyev, 1895. $1446 \mathrm{~s}$.

19. Derzharkhiv Odesjkoji oblasti. F. 22. Imperatorsjke tovarystvo siljsjkogho ghospodarstva Pivdnja Rosiji.

20. Derzharkhiv Kharkivsjkoji oblasti. F. 304. Kharkivsjka ghubernsjka zemsjka uprava.

21. Spravochnыj lystok.

22. CDIAK Ukrajiny. F. 731. Kyjivsjke tovarystvo siljsjkogho ghospodarstva $i$ siljsjkoghospodarsjkoji promyslovosti.

23. CDIAK Ukrajiny. F. 573. Kyjivsjke tovarystvo zakhidnykh zemstv z prodazhu siljsjkoghospodarsjkykh mashyn, m. Kyjiv.

24. Juzhnorusskaja seljskokhozjajstvennaja ghazeta.

25. Derzharkhiv Kharkivsjkoji oblasti. F.237. Kharkivsjke tovarystvo siljsjkogho ghospodarstva i siljsjkoghospodarsjkoji promyslovosti.

26. Derzharkhiv Zaporizjkoji oblasti. F. 56. Oleksandrivsjka povitova zemsjka uprava.

27. Juzhnoe khozjajstvo.

28. Derzharkhiv Zhytomyrsjkoji oblasti. F. 187. Volynsjke tovarystvo khmeljarstva. 
Лисенко М. С.

кандидат історичних наук, доцент, Харківський національній університет міського господарства ім. О. М. Бекетова, м. Харків (Україна). ORCID: 0000-00024135-4345.

МІЖНАРОДНЕ СПІВРОБІТНИЦТВО АГРАРНИХ ГРОМАДСЫКИХОРГАНІЗАЦІЙ УКРАЇНСЫКИХ ГУБЕРНІЙ РОСІЙСЬКОЇ ІМПЕРЇ̈(ПОЧАТОКХХ СТ.)

Метою статті є вивчення міжнародного співробітництва аграрних товариств $i$ його впливу на модернізацію українських губерній. 3 'ясовано, щзо міжнародна діяльність розвивалася від особистих зв'язків до багатостороннєго співробітництва. До завдань громадськості варто віднести проведення численних заходів. Автором відтворено проиес участі членів аграрних организачій у різних міжнародних заходах, зокрема виставках. Підкреслено, що иі контакти мали обопільний інтерес. Вони надавали можливість членам добровільних асоціацій переймати зарубіжний досвід.

Значну увагу приділено ініціативам окремих осіб - членів сільськогосподарських товариств. У статті вивчене питання проведення аграрними об'єднаннями екскурсій, практик для місиевих землевласників за кордоном. Нами звернута увага на широке коло країн, з якими співпрацювали представники аграрних товариств. Ініциатива аграрних громадських організаџій отримала допомогу уряду, були засновані експортні палати. Сільськогосподарські товариства стали їх активними учасниками та співзасновниками. Зроблено висновок про те, шо перейняття зарубіжного досвіду $і$ контакти $з$ іноземними організаціями і фахівцями сприяли якісним змінам у суспільстві.

Ключові слова: Російська імперія, українські губернії, громадська організачія, сільськогосподарські товариства, сільське господарство, міжнародне співробітництво.

Отримано 26.05.2021 